\title{
STK15 Phe31Ile and Val57Ile Polymorphisms Increase the Risk of Gastrointestinal Cancer
}

(Polimorfisme STK15 Phe31Ile dan Val57Ile Meningkatkan Risiko terhadap Kanser Gastrousus)

\author{
TianXin Lai, ERic Tzyy Jiann ChOng, JitT Aun ChuAh, KeK Heng ChuA \& Ping-Chin LeE**
}

\begin{abstract}
STK15 is a serine/threonine kinase that regulates chromosomal segregation during mitosis. Single nucleotide polymorphisms (SNPS) in this gene, Phe31Ile (rs2273535) and Val57Ile (rs 1047972), are inconsistently associated with gastrointestinal cancer (GIC) across different populations. However, this association is unclear in Malaysian population. Therefore, this study investigated the association of STK15 Phe31Ile and Val57Ile polymorphisms to GIC risk in Malaysia. Genomic DNA was extracted from 185 GIC patients and 1110 healthy controls and was subjected to polymerase chain reaction-restriction fragment length polymorphism (PCR-RFLP) analysis. SNPs were further confirmed using sequencing. We found that the 31Phe allele and 31Phe/Phe genotype in the Phe31Ile SNP significantly increased GIC risk in Malaysian population, particularly in gastric cancer $(\mathrm{p}<0.017)$. The combined analysis for both SNPs also increased the risk of GIC in this study. Etiological factors such as age, gender and ethnicity were not associated with GIC in the population. This is the first study to report the association of STK15 Phe31Ile and Val57Ile SNPs with an increased risk of GIC in Malaysians; the 31Phe allele is exclusively associated with the risk of gastric cancer. In addition, GIC incidences among Malaysians have significantly shifted to a younger age ( $<50$ years).
\end{abstract}

Keywords: Gastrointestinal cancer; Malaysian population; STK15 polymorphisms

\section{ABSTRAK}

STK15 adalah kinase serin/treonina yang mengawal perpisahan kromosom semasa mitosis. Polimorfisme nukleotida tunggal (SNPS) pada gen ini, Phe31Ile (rs2273535) dan Val57Ile (rs1047972) adalah dikaitkan dengan kanser gastrousus (GIC) secara tidak tekal dalam populasi yang berbeza. Walau bagaimanapun, perkaitan tersebut adalah tidak jelas di dalam populasi di Malaysia. Oleh itu, penyelidikan ini mengkaji perkaitan bagi polimorfisme STK15 Phe31Ile dan Val57Ile terhadap risiko GIC di Malaysia. DNA genom diekstrak daripada 185 pesakit GIC dan 1110 kawalan yang sihat. Seterusnya, analisis tindak balas berantai polimerase pemotongan panjang cebisan (PCR-RFLP) dijalankan dan SNP turut disahkan dengan menggunakan teknik penjujukan DNA. Kami mendapati bahawa alel 31 Phe dan genotip 31Phe/Phe dalam SNP Phe31Ile meningkatkan risiko terhadap GIC dalam populasi di Malaysia secara signifikan, terutamanya dalam kanser gastrik (p<0.017). Analisis gabungan bagi kedua-dua SNP juga meningkatkan risiko terhadap GIC dalam kajian ini. Faktor etiologi seperti umur, jantina dan etnik adalah tidak berkait dengan GIC dalam populasi ini. Kajian ini merupakan kajian pertama yang melaporkan tentang perkaitan antara SNP STK15 Phe31Ile dan Val57Ile dengan peningkatan risiko terhadap GIC di Malaysia; terutamanya alel 31 Phe yang dikaitkan dengan risiko kanser gastrik. Selain itu, kejadian GIC dalam kalangan rakyat Malaysia telah beralih secara signifikan kepada usia yang lebih muda (<50 tahun).

Kata kunci: Kanser gastrousus; polimorfisme STK15; populasi Malaysia

\section{INTRODUCTION}

STK15 is a serine/threonine kinase involved in mitotic entry, separation of centriole pairs, accurate bipolar spindle assembly, and chromosome alignment during the metaphase in a cell (Dutertre et al. 2002). STK15 maps to chromosome 20q13.2, a common site of amplification in tumours. It has been shown to have a low penetrance cancer susceptibility gene that affects multiple cancer types (Ewart-Toland et al. 2005). Over-expression of this gene is oncogenic because it causes centrosome amplification, chromosome instability, transformation in vitro and tumorigenesis in mammalian cell lines (Bischoff et al.
1998; Sakakura et al. 2001). A recent study also reported a significant up-regulation of STK15 in esophageal squamous cell carcinoma tumors when compared to normal tissues (Chen et al. 2014).

There are two polymorphic sites of STK15, namely, the Phe31Ile (rs2273535) and Val57Ile (rs1047972) that are reported to affect the pathogenesis of cancer. These two single nucleotide polymorphisms (SNPs) are in the conserved region of the $\mathrm{NH} 2$-terminal region that is involved in ubiquitin-based proteolysis (Honda et al. 2000). Amino acid 31Phe binds with the E2 ubiquitin conjugating enzyme $U B E 2 N$ during mitosis at the centrosome. Loss of 
UBE2N binding function with the STK15 variant has been reported to increase susceptibility to human cancer (EwartToland et al. 2003). The function of Val57Ile SNP has not been identified. However, it might be important for kinases activity as the 57Ile homozygote genotype has $57.5 \%$ less kinases activity and showed more chromosome instability than the 57Val homozygote genotype (Dogan et al. 2008). These two SNPs are associated independently with both sporadic and hereditary cancers, especially in gastrointestinal cancer (GIC) including esophageal, gastric, pancreas, and colorectal as well as other cancers such as breast, ovarian and lung through case-control or metaanalysis studies in different populations (Chen et al. 2014, 2007; Chong et al. 2016; Dai et al. 2014; Ju et al. 2006; Kimura et al. 2005; Qin et al. 2015; Tang et al. 2013; Xu et al.2014). We have previously reported that carriers with at least one copy of the c2 allele in the CYP2E1 gene was associated to GIC in Malaysians (Chong et al. 2014), but the association of the Phe31Ile and Val57Ile SNPS in STK15 to GIC in the population is still unclear. Furthermore, previous studies of these SNPs in different populations showed contradicting outcomes and inconsistent associations. Therefore, we conducted this study to screen the frequency of these STK15 SNPS and to determine the association with the risk of getting GIC in Malaysian GIC patients.

\section{MATERIALS AND METHODS}

\section{SUBJECTS AND SAMPLE COLLECTION}

A total of 185 GIC patients (gastric $=41$, colorectal $=$ 126 , esophageal $=4$, pancreas $=7$, liver $=3$ and anus $=$ 4) who were admitted to Queen Elizabeth Hospital, Kota Kinabalu, Sabah and University Malaya Medical Centre, Kuala Lumpur and 1110 healthy volunteers randomly selected during blood donation campaigns were recruited from 2010 to 2014. This study conforms to The Code of Ethics of the World Medical Association (Declaration of Helsinki) and written consent was obtained from all subjects. Five $\mathrm{mL}$ of peripheral blood was obtained in BD Vacutainer ${ }^{\circledR}$ containing EDTA (Becton Dickinson, New Jersey, USA), and data including age, gender and ethnicity were collected from all subjects. Clinical characteristics for GIC and lifestyles of the subjects were not available as data collection was limited; this study solely focused on the association of the STK15 gene polymorphisms to GIC. Overall, $68.03 \%$ of the study population were male, while $31.97 \%$ were female with age ranging from 15 to 93 years (mean age \pm S.D. $=31.93 \pm 14.83$ ) and comprised of Malaysian Chinese (22.08\%), Malay (9.03\%), Malaysian Indian (3.71\%), Kadazan-Dusun (24.40\%), Bajau (9.34\%) and other ethnicities $(31.44 \%)$ that are indigenous in East Malaysia. This study was approved by Sabah State Health Department and Queen Elizabeth Hospital, Kota Kinabalu and the ethical approval was obtained from the University Malaya Medical Centre (UMMC) Ethical Board with Ref. 654.1 .

\section{STK15 GENOTYPING AND DIRECT SEQUENCING}

Genomic DNA was extracted using an alkaline phenol-chloroform lysis method from whole blood, and genotyping was carried out using a polymerase chain reaction followed by restriction fragment length polymorphism (PCR-RFLP) analysis. Primers used were 5'-CTTTCATGAATGCCAGAAAGTT-3'/5' CTGGGAAGAATTTGAAGGACA-3' for Phe31Ile SNP and 5'-CTTTCATGAATGCCAGAAAGTT-3'/5'CTGCTTCTGATTCTGAACCGGCTTG-3' for Val57Ile SNPstudies, respectively. The PCR reaction was carried out in a $25 \mu \mathrm{L}$ volume containing $100 \mathrm{ng}$ of extracted DNA, $0.2 \mu \mathrm{M}$ of each primer, $0.2 \mathrm{mM}$ of each dNTPs, $1.5 \mathrm{mM}$ of $\mathrm{MgCl} 2$ and 1 unit of HotStarTaq ${ }^{\circledR}$ DNA polymerase (Qiagen, Germany). The reaction was performed with the following conditions: 1 cycle for $15 \mathrm{~min}$ at $95^{\circ} \mathrm{C} ; 35$ cycles for $30 \mathrm{~s}$ at $94^{\circ} \mathrm{C}, 30 \mathrm{~s}$ at $55^{\circ} \mathrm{C}$ and $30 \mathrm{~s}$ at $72^{\circ} \mathrm{C}$; and a final elongation step for $7 \mathrm{~min}$ at $72^{\circ} \mathrm{C}$ for both primer sets. The PCR product was digested with 5 units of ApoI (NEB Inc., Ipswich, MA) at $50^{\circ} \mathrm{C}$ overnight for Phe31Ile polymorphism and 5 units of $B s t \mathrm{UI}$ (NEB Inc., Ipswich, MA) at $60^{\circ} \mathrm{C}$ overnight for Val57Ile polymorphism. The resulting fragments were analyzed with $3 \%$ agarose gel electrophoresis. PCR products for both polymorphisms were sequenced using the ABI PRISM 3100 Genetic Analyzer (Applied Biosystems, USA) for confirmation.

\section{STATISTICAL ANALYSIS}

The Hardy-Weinberg equilibrium (HWE) was tested for genotype distribution in controls and cases for both polymorphisms, which were represented by $\chi^{2}$ value (within HWE if $\chi^{2}<3.84, d f=1$ ). By taking the $31 \mathrm{Ile}$ and 31Ile/Ile for Phe31Ile and 57Val and 57Val/Val for Val57Ile SNPs as reference, SPSS Software V17.0 (SPSS Inc, Chicago, Illinois, USA) was used to estimate the allelic and genotypic interactions in GIC development by calculating the odd's ratio (OR) and $95 \%$ confidence interval $(95 \% \mathrm{CI})$. The interactions were statistically significant when the $p$-value was less than 0.05 using the Fisher's exact test. For the sub-group analysis, the association test was considered statistically significant only after Bonferroni correction.

\section{RESULTS}

Genotype distributions were tested for Phe31Ile (cases, $\chi^{2}=0.30$; controls, $\chi^{2}=1.22$ ) and Val57Ile (cases, $\chi^{2}=<$ 0.01 ; controls, $\chi^{2}=0.55$ ) SNPs and they were within the HWE. The heterozygousity and homozygousity for both SNPS were sequenced and matched with the PCR-RFLP analysis data. For the Phe31Ile SNP, the 31Ile and 31Phe allele frequencies among all the subjects were $59.19 \%$ and $40.81 \%$, respectively. The genotype frequency was $34.29 \%$ for $31 \mathrm{Ile} / \mathrm{Ile}, 49.81 \%$ for $31 \mathrm{Phe} / \mathrm{Ile}$ and $15.90 \%$ for $31 \mathrm{Phe} /$ Phe (Table 1). The 31Phe allele and 31Phe/Phe genotype showed a strong significant association with an increased risk of GIC, especially in gastric cancer with Bonferroni correction (Table 2). 
TABLE 1. Risk association of STK15 Phe31Ile and Val57Ile polymorphisms to GIC in Malaysians

\begin{tabular}{|c|c|c|c|c|}
\hline & Cases, $N$ & Controls, $N$ & OR $(95 \% \mathrm{CI})$ & $p$-value \\
\hline \multicolumn{5}{|l|}{ Phe31Ile SNP } \\
\hline \multicolumn{5}{|l|}{ Allele } \\
\hline 31 Ile & 194 & 1339 & 1.00 (Reference) & - \\
\hline 31 Phe & 176 & 881 & $1.38(1.11-1.72)$ & $0.005 *$ \\
\hline \multicolumn{5}{|l|}{ Genotype } \\
\hline 31 Ile/Ile & 49 & 395 & 1.00 (Reference) & - \\
\hline 31 Phe/Ile & 96 & 549 & $1.41(0.98-2.04)$ & 0.070 \\
\hline $31 \mathrm{Phe} / \mathrm{Phe}$ & 40 & 166 & $1.94(1.23-3.06)$ & $0.005^{*}$ \\
\hline 31 Phe/Ile + 31 Phe/Phe & 136 & 715 & $1.53(1.08-2.17)$ & $0.015^{*}$ \\
\hline \multicolumn{5}{|l|}{ Val57Ile SNP } \\
\hline \multicolumn{5}{|l|}{ Allele } \\
\hline $57 \mathrm{Val}$ & 303 & 1872 & 1.00 (Reference) & - \\
\hline $57 \mathrm{Ile}$ & 67 & 348 & $1.19(0.89-1.59)$ & 0.251 \\
\hline \multicolumn{5}{|l|}{ Genotype } \\
\hline $57 \mathrm{Val} / \mathrm{Val}$ & 124 & 786 & 1.00 (Reference) & - \\
\hline $57 \mathrm{Val} / \mathrm{Ile}$ & 55 & 300 & $1.16(0.82-1.64)$ & 0.419 \\
\hline 57 Ile/Ile & 6 & 24 & $1.59(0.64-3.95)$ & 0.289 \\
\hline $57 \mathrm{Val} / \mathrm{Ile}+57 \mathrm{Ile} / \mathrm{Ile}$ & 61 & 324 & $1.19(0.86-1.66)$ & 0.298 \\
\hline \multicolumn{5}{|l|}{ Phe31Ile + Val57Ile SNPs } \\
\hline \multicolumn{5}{|l|}{ Allele } \\
\hline $31 \mathrm{Ile}+57 \mathrm{Val}$ & 497 & 3211 & 1.00 (Reference) & - \\
\hline $31 \mathrm{Phe}+57 \mathrm{Ile}$ & 243 & 1229 & $1.28(1.08-1.51)$ & $0.005^{*}$ \\
\hline \multicolumn{5}{|l|}{ Genotype } \\
\hline $31 \mathrm{Ile} / \mathrm{Ile}+57 \mathrm{Val} / \mathrm{Val}$ & 173 & 1181 & 1.00 (Reference) & - \\
\hline $31 \mathrm{Phe} / \mathrm{Ile}+57 \mathrm{Val} / \mathrm{Ile}$ & 151 & 849 & $1.21(0.96-1.54)$ & 0.116 \\
\hline 31 Phe/Ile + 57 Ile/Ile & 102 & 573 & $1.22(0.93-1.58)$ & 0.149 \\
\hline $31 \mathrm{Phe} / \mathrm{Phe}+57 \mathrm{Val} / \mathrm{Ile}$ & 95 & 466 & $1.39(1.06-1.83)$ & $0.020 *$ \\
\hline $31 \mathrm{Phe} / \mathrm{Phe}+57$ Ile/Ile & 46 & 190 & $1.65(1.15-2.37)$ & $0.008 *$ \\
\hline
\end{tabular}

$*$, statistical significant $(p<0.05)$

$\mathrm{SNP}=$ single nucleotide polymorphism, $N=$ number of samples, $\mathrm{OR}=$ odd ratio, $\mathrm{CI}=$ confidence interval, Ile $=$ isoleucine, $\mathrm{Phe}=$ phenylalanine, $\mathrm{Val}=$ valine

In the Val57Ile SNP analysis, $83.98 \%$ of allele frequency was the $57 \mathrm{Val}$, while for $57 \mathrm{Ile}$, it was $16.02 \%$ in this study. The genotype distributions for $57 \mathrm{Val} / \mathrm{Val}$, $57 \mathrm{Val} / \mathrm{Ile}$ and $57 \mathrm{Ile} / \mathrm{Ile}$ were $70.27 \%, 27.41 \%$, and $2.32 \%$, respectively. There was no significant evidence for this SNP to increase the risk of GIC, but the combined analysis of the Phe31Ile and Val57Ile SNPs showed that the 31Phe $+57 \mathrm{Ile}$ alleles as well as the $31 \mathrm{Phe} / \mathrm{Phe}+57 \mathrm{Val} / \mathrm{Ile}$ and 31 Phe/Phe + 57Ile/Ile genotypes increased the risk to GIC significantly in the Malaysian population. Etiological factors including age, gender and ethnicity were not associated with GIC for both SNPs in this study (Tables 3 and 4).

\section{DISCUSSION}

To the best of our knowledge, this is the first study to report a significant risk association of the STK15 Phe31Ile and Val57Ile SNPS with GIC in the Malaysian population by including indigenous ethnics in East Malaysia. By using MuPro software (Cheng et al. 2006), the presence of the Phe31Ile SNP in the STK15 gene has been predicted to decrease the stability of the protein structure (confidence score $=-0.577)$ whereas the Val57Ile SNP appears to increase the stability of the gene (confidence score $=$ 0.038). The conflicting predictions of both SNPs towards the stability of the protein structure making them worth to be studied, especially their associations to the risk of GIC that encounter approximately 2.9 million of deaths globally in 2012 (IARC 2014) and mortality rate of 4.71 per 0.1 million of populations in Malaysia (Department of Health Statistics Malaysia 2013) and the mortality rate for GIC is projected to increase continuously in the future. In this study, we mainly focused on gastric and colorectal cancers due to our sample limitation.

A previous study reported that the 31Ile allele in Phe31Ile SNP was more common in Asian (Ewart-Toland et al. 2005) and therefore we took it as the reference allele in this study. We found that the 31Phe allele and the 31Phe/Phe genotype elevated the risk of GIC in our Malaysian sample, mainly in gastric cancer even after the Bonferroni correction; suggesting that the $31 \mathrm{Phe}$ allele is highly associated with increased risk of GIC and may act as a biomarker for early detection of gastric cancer in the Malaysian population. Although the presence of 31Phe was not associated with esophageal cancer in this study, contradicting results were previously reported where Kimura et al. (2005) claimed that 31Phe/Phe genotype 
TABLE 2. Risk association of STK15 Phe31Ile and Val57Ile polymorphisms to different types of GIC in Malaysians

\begin{tabular}{|c|c|c|c|c|}
\hline & Cases, $N$ & Controls, $N$ & OR $(95 \% \mathrm{CI})$ & $p$-value \\
\hline \multicolumn{5}{|l|}{ Phe31Ile SNP } \\
\hline \multicolumn{5}{|l|}{ Gastric } \\
\hline 31 Ile/Ile & 6 & 395 & 1.00 (Reference) & - \\
\hline $31 \mathrm{Phe} / \mathrm{Ile}$ & 18 & 549 & $2.16(0.85-5.49)$ & 0.106 \\
\hline $31 \mathrm{Phe} / \mathrm{Phe}$ & 17 & 166 & $6.74(2.61-17.40)$ & $<0.001 *$ \\
\hline $31 \mathrm{Phe} / \mathrm{Ile}+31 \mathrm{Phe} / \mathrm{Phe}$ & 35 & 715 & $3.22(1.34-7.73)$ & $0.009 *$ \\
\hline \multicolumn{5}{|l|}{ Colorectal } \\
\hline $31 \mathrm{Ile} / \mathrm{Ile}$ & 40 & 395 & 1.00 (Reference) & - \\
\hline $31 \mathrm{Phe} / \mathrm{Ile}$ & 69 & 549 & $1.24(0.82-1.87)$ & 0.302 \\
\hline $31 \mathrm{Phe} / \mathrm{Phe}$ & 17 & 166 & $1.01(0.56-1.83)$ & 0.971 \\
\hline 31 Phe/Ile + 31 Phe/Phe & 86 & 715 & $1.19(0.80-1.76)$ & 0.393 \\
\hline \multicolumn{5}{|l|}{ Others** } \\
\hline $31 \mathrm{Ile} / \mathrm{Ile}$ & 3 & 395 & 1.00 (Reference) & - \\
\hline $31 \mathrm{Phe} / \mathrm{Ile}$ & 9 & 549 & $2.16(0.58-8.02)$ & 0.251 \\
\hline $31 \mathrm{Phe} / \mathrm{Phe}$ & 6 & 166 & $4.76(1.18-19.25)$ & 0.029 \\
\hline $31 \mathrm{Phe} / \mathrm{Ile}+31 \mathrm{Phe} / \mathrm{Phe}$ & 15 & 715 & $2.76(0.79-9.60)$ & 0.110 \\
\hline \multicolumn{5}{|l|}{ Val57Ile SNP } \\
\hline \multicolumn{5}{|l|}{ Gastric } \\
\hline $57 \mathrm{Val} / \mathrm{Val}$ & 25 & 786 & 1.00 (Reference) & - \\
\hline $57 \mathrm{Val} / \mathrm{Ile}$ & 15 & 300 & $1.57(0.82-3.02)$ & 0.175 \\
\hline 57 Ile/Ile & 1 & 24 & $1.31(0.17-10.07)$ & 0.795 \\
\hline $57 \mathrm{Val} / \mathrm{Ile}+57 \mathrm{Ile} / \mathrm{Ile}$ & 16 & 324 & $1.55(0.82-2.95)$ & 0.178 \\
\hline \multicolumn{5}{|l|}{ Colorectal } \\
\hline $57 \mathrm{Val} / \mathrm{Val}$ & 89 & 786 & 1.00 (Reference) & - \\
\hline $57 \mathrm{Val} / \mathrm{Ile}$ & 32 & 300 & $0.94(0.62-1.44)$ & 0.783 \\
\hline 57 Ile/Ile & 5 & 24 & $1.84(0.68-4.94)$ & 0.227 \\
\hline $57 \mathrm{Val} / \mathrm{Ile}+57 \mathrm{Ile} / \mathrm{Ile}$ & 37 & 324 & $1.01(0.67-1.52)$ & 0.967 \\
\hline \multicolumn{5}{|l|}{ Others $* *$} \\
\hline $57 \mathrm{Val} / \mathrm{Val}$ & 10 & 786 & 1.00 (Reference) & - \\
\hline $57 \mathrm{Val} / \mathrm{Ile}$ & 8 & 300 & $2.10(0.82-5.36)$ & 0.123 \\
\hline 57 Ile/Ile & 0 & 24 & - & - \\
\hline $57 \mathrm{Val} / \mathrm{Ile}+57 \mathrm{Ile} / \mathrm{Ile}$ & 8 & 324 & $1.94(0.76-4.96)$ & 0.166 \\
\hline
\end{tabular}

*, statistical significant with Bonferroni correction $(p<0.017)$; **, including esophageal $(N=4)$, pancreas $(N=7)$, liver $(N=3)$, and anus $(N=4)$ $\mathrm{SNP}=$ single nucleotide polymorphism,$N=$ number of samples, $\mathrm{OR}=$ odd ratio, $\mathrm{CI}=$ confidence interval, Ile $=$ isoleucine, $\mathrm{Phe}=$ phenylalanine, $\mathrm{Val}=$ valine

increased the risk of esophageal cancer $(\mathrm{OR}=1.93,95 \%$ $\mathrm{CI}=0.90-4.16$ ) but Miao et al. (2004) showed that 31Ile/ Ile genotype was significantly associated with increased risk of esophageal cancer $(\mathrm{OR}=1.97,95 \% \mathrm{CI}=1.36-2.85)$. Interestingly, Pan et al. (2012) reported that 31Phe/Ile genotype was significantly associated with recurrence of esophageal cancer with $\mathrm{OR}=4.39(95 \% \mathrm{CI}=2.12-8.94)$. Therefore, SNP association studies targeting specific type of GIC cancers are needed in the future for more precise risk estimation and healthcare approaches given to each cancer should be distinguished empirically in the Malaysian population.

We had no evidence to associate the variant allele and genotype in Val57Ile SNP alone to an increase in the risk of GIC, but past studies showed that the 57Ile/Ile genotype was protective against lung cancer in Caucasians $(\mathrm{OR}=0.72,95 \% \mathrm{CI}=0.41-1.26)$ and breast cancer in Han Chinese (OR $=0.8,95 \% \mathrm{CI}=0.4-1.6$ ) (Dai et al. 2004; $\mathrm{Gu}$ et al. 2007), indicating that the Val57Ile SNP affects different cancer development across different populations.
However, combined analysis of both SNPS in this study showed an increase risk to GIC significantly. Since STK 15 is a low penetrance gene, it is discrepant to claim that the gene alone is the significant genetic factor to GIC regardless of the influence of the environmental factors. Therefore, additional work on gene-environmental interactions to GIC development should be conducted for validation.

In this study, age and STK15 polymorphisms were not interacting factors that contributed to GIC, but we noticed that around $26.49 \%$ of GIC patients in our database were less than 50 years old. This statistic was much higher than those previously reported by the Malaysian GastroIntestinal Registry (MGIR) with only 18.14\% (MGIR 2009); this suggests that GIC cases are becoming common among younger individuals and therefore screening for GIC should be performed before 50 years old among Malaysians to obtain better survival rates from GIC.

Previously, we have reported that females had a nearly two-fold higher risk to GIC in the Malaysian population, but we did not analyze the association of different genotypes to 
TABLE 3. Association of age, gender and ethnicity in STK15 Phe31Ile SNP to GIC

\begin{tabular}{|c|c|c|c|c|}
\hline & Cases, $N$ & Controls, $N$ & OR $(95 \% \mathrm{CI})$ & $p$-value \\
\hline \multicolumn{5}{|l|}{ Age } \\
\hline \multicolumn{5}{|l|}{$<50$ years } \\
\hline Ile/Ile & 14 & 379 & 1.00 (Reference) & - \\
\hline Phe/Ile & 23 & 531 & $1.17(0.60-2.31)$ & 0.645 \\
\hline Phe/Phe & 12 & 160 & $2.03(0.92-4.49)$ & 0.080 \\
\hline Phe/Ile + Phe/Phe & 35 & 691 & $1.37(0.73-2.58)$ & 0.328 \\
\hline \multicolumn{5}{|l|}{$\geq 50$ years } \\
\hline Ile/Ile & 35 & 16 & 1.00 (Reference) & - \\
\hline Phe/Ile & 73 & 18 & $1.85(0.85-4.06)$ & 0.123 \\
\hline Phe/Phe & 28 & 6 & $2.13(0.74-6.17)$ & 0.162 \\
\hline Phe/Ile + Phe/Phe & 101 & 24 & $1.92(0.92-4.03)$ & 0.083 \\
\hline \multicolumn{5}{|l|}{ Gender } \\
\hline \multicolumn{5}{|l|}{ Male } \\
\hline Ile/Ile & 23 & 295 & 1.00 (Reference) & - \\
\hline Phe/Ile & 50 & 383 & $1.67(1.00-2.81)$ & 0.061 \\
\hline Phe/Phe & 17 & 113 & $1.93(0.99-3.75)$ & 0.066 \\
\hline Phe/Ile + Phe/Phe & 67 & 496 & $1.73(1.06-2.84)$ & 0.028 \\
\hline \multicolumn{5}{|l|}{ Female } \\
\hline Ile/Ile & 26 & 100 & 1.00 (Reference) & - \\
\hline Phe/Ile & 46 & 166 & $1.07(0.62-1.83)$ & 0.891 \\
\hline Phe/Phe & 23 & 53 & $1.67(0.87-3.21)$ & 0.131 \\
\hline Phe/Ile + Phe/Phe & 69 & 219 & $1.21(0.73-2.02)$ & 0.526 \\
\hline \multicolumn{5}{|l|}{ Ethnicity } \\
\hline \multicolumn{5}{|l|}{ Chinese } \\
\hline Ile/Ile & 18 & 97 & 1.00 (Reference) & - \\
\hline Phe/Ile & 33 & 100 & $1.78(0.94-3.37)$ & 0.084 \\
\hline Phe/Phe & 12 & 26 & $2.49(1.06-5.81)$ & 0.057 \\
\hline Phe/Ile + Phe/Phe & 45 & 126 & $1.93(1.05-3.53)$ & 0.041 \\
\hline \multicolumn{5}{|l|}{ Malay } \\
\hline Ile/Ile & 2 & 38 & 1.00 (Reference) & - \\
\hline Phe/Ile & 5 & 50 & $1.90(0.35-10.33)$ & 0.695 \\
\hline Phe/Phe & 0 & 22 & - & - \\
\hline Phe/Ile + Phe/Phe & 5 & 72 & $1.32(0.24-7.12)$ & 1.000 \\
\hline \multicolumn{5}{|l|}{ Indian } \\
\hline Ile/Ile & 0 & 5 & 1.00 (Reference) & - \\
\hline Phe/Ile & 2 & 21 & - & - \\
\hline Phe/Phe & 0 & 20 & - & - \\
\hline Phe/Ile + Phe/Phe & 2 & 41 & - & - \\
\hline \multicolumn{5}{|l|}{ Kadazan-Dusun } \\
\hline Ile/Ile & 14 & 95 & 1.00 (Reference) & - \\
\hline Phe/Ile & 27 & 133 & $1.38(0.69-2.77)$ & 0.393 \\
\hline Phe/Phe & 14 & 33 & $2.88(1.24-6.67)$ & 0.021 \\
\hline Phe/Ile + Phe/Phe & 41 & 166 & $1.68(0.87-3.23)$ & 0.160 \\
\hline \multicolumn{5}{|l|}{ Bajau } \\
\hline Ile/Ile & 6 & 41 & 1.00 (Reference) & - \\
\hline Phe/Ile & 10 & 46 & $1.49(0.50-4.45)$ & 0.589 \\
\hline Phe/Phe & 6 & 12 & $3.42(0.93-12.56)$ & 0.077 \\
\hline Phe/Ile + Phe/Phe & 16 & 58 & $1.89(0.68-5.23)$ & 0.239 \\
\hline \multicolumn{5}{|l|}{ Others } \\
\hline Ile/Ile & 9 & 119 & 1.00 (Reference) & - \\
\hline Phe/Ile & 19 & 199 & $1.26(0.55-2.88)$ & 0.685 \\
\hline Phe/Phe & 8 & 53 & $2.00(0.73-5.46)$ & 0.183 \\
\hline Phe/Ile + Phe/Phe & 27 & 252 & $1.42(0.65-3.11)$ & 0.455 \\
\hline
\end{tabular}

$N=$ number of samples, $\mathrm{OR}=$ odd ratio, $\mathrm{CI}=$ confidence interval, $\mathrm{Ile}=$ isoleucine, $\mathrm{Phe}=$ phenylalanine 
TABLE 4. Association of age, gender, and ethnicity in STK15 Val57Ile SNP to GIC

\begin{tabular}{|c|c|c|c|c|}
\hline & Cases, $N$ & Controls, $N$ & OR $(95 \% \mathrm{CI})$ & $p$-value \\
\hline \multicolumn{5}{|l|}{ Age } \\
\hline \multicolumn{5}{|l|}{$<50$ years } \\
\hline Val/Val & 31 & 753 & 1.00 (Reference) & - \\
\hline $\mathrm{Val} / \mathrm{Ile}$ & 15 & 293 & $1.24(0.66-2.34)$ & 0.498 \\
\hline Ile/Ile & 3 & 24 & $3.04(0.87-10.63)$ & 0.082 \\
\hline Val/Ile + Ile/Ile & 18 & 317 & $1.38(0.76-2.50)$ & 0.290 \\
\hline \multicolumn{5}{|l|}{$\geq 50$ years } \\
\hline $\mathrm{Val} / \mathrm{Val}$ & 93 & 33 & 1.00 (Reference) & - \\
\hline $\mathrm{Val} / \mathrm{Ile}$ & 40 & 7 & $2.03(0.83-4.97)$ & 0.122 \\
\hline Ile/Ile & 3 & 0 & - & - \\
\hline Val/Ile + Ile/Ile & 43 & 7 & $2.18(0.89-5.32)$ & 0.087 \\
\hline \multicolumn{5}{|l|}{ Gender } \\
\hline \multicolumn{5}{|l|}{ Male } \\
\hline $\mathrm{Val} / \mathrm{Val}$ & 63 & 574 & 1.00 (Reference) & - \\
\hline Val/Ile & 25 & 202 & $1.13(0.69-1.84)$ & 0.612 \\
\hline Ile/Ile & 2 & 15 & $1.22(0.27-5.43)$ & 0.682 \\
\hline Val/Ile + Ile/Ile & 27 & 217 & $1.13(0.70-1.83)$ & 0.620 \\
\hline \multicolumn{5}{|l|}{ Female } \\
\hline $\mathrm{Val} / \mathrm{Val}$ & 61 & 212 & 1.00 (Reference) & - \\
\hline $\mathrm{Val} / \mathrm{Ile}$ & 30 & 98 & $1.06(0.65-1.75)$ & 0.800 \\
\hline Ile/Ile & 4 & 9 & $1.55(0.46-5.19)$ & 0.501 \\
\hline Val/Ile + Ile/Ile & 34 & 107 & $1.10(0.68-1.78)$ & 0.712 \\
\hline \multicolumn{5}{|l|}{ Ethnicity } \\
\hline \multicolumn{5}{|l|}{ Chinese } \\
\hline $\mathrm{Val} / \mathrm{Val}$ & 45 & 186 & 1.00 (Reference) & - \\
\hline $\mathrm{Val} / \mathrm{Ile}$ & 16 & 34 & $1.95(0.99-3.83)$ & 0.060 \\
\hline Ile/Ile & 2 & 3 & $2.76(0.45-16.98)$ & 0.260 \\
\hline Val/Ile + Ile/Ile & 18 & 37 & $2.01(1.05-3.85)$ & 0.045 \\
\hline \multicolumn{5}{|l|}{ Malay } \\
\hline $\mathrm{Val} / \mathrm{Val}$ & 6 & 85 & 1.00 (Reference) & - \\
\hline $\mathrm{Val} / \mathrm{Ile}$ & 1 & 25 & $0.57(0.07-4.93)$ & 1.000 \\
\hline Ile/Ile & 0 & 0 & - & - \\
\hline Val/Ile + Ile/Ile & 1 & 25 & $0.57(0.07-4.93)$ & 1.000 \\
\hline \multicolumn{5}{|l|}{ Indian } \\
\hline $\mathrm{Val} / \mathrm{Val}$ & 2 & 35 & 1.00 (Reference) & - \\
\hline $\mathrm{Val} / \mathrm{Ile}$ & 0 & 11 & - & - \\
\hline Ile/Ile & 0 & 0 & - & - \\
\hline Val/Ile + Ile/Ile & 0 & 11 & - & - \\
\hline \multicolumn{5}{|l|}{ Kadazan-Dusun } \\
\hline Val/Val & 30 & 166 & 1.00 (Reference) & - \\
\hline $\mathrm{Val} / \mathrm{Ile}$ & 23 & 87 & $1.46(0.80-2.67)$ & 0.270 \\
\hline Ile/Ile & 2 & 8 & $1.38(0.28-6.84)$ & 0.656 \\
\hline Val/Ile + Ile/Ile & 25 & 95 & $1.46(0.81-2.62)$ & 0.224 \\
\hline \multicolumn{5}{|l|}{ Bajau } \\
\hline $\mathrm{Val} / \mathrm{Val}$ & 15 & 72 & 1.00 (Reference) & - \\
\hline $\mathrm{Val} / \mathrm{Ile}$ & 6 & 23 & $1.25(0.44-3.60)$ & 0.781 \\
\hline Ile/Ile & 1 & 4 & $1.20(0.13-11.51)$ & 1.000 \\
\hline Val/Ile + Ile/Ile & 7 & 27 & $1.24(0.46-3.38)$ & 0.794 \\
\hline \multicolumn{5}{|l|}{ Others } \\
\hline $\mathrm{Val} / \mathrm{Val}$ & 26 & 186 & 1.00 (Reference) & - \\
\hline $\mathrm{Val} / \mathrm{Ile}$ & 9 & 34 & $1.89(0.82-4.39)$ & 0.146 \\
\hline Ile/Ile & 1 & 3 & $2.39(0.24-23.79)$ & 0.416 \\
\hline $\mathrm{Val} / \mathrm{Ile}+\mathrm{Ile} / \mathrm{Ile}$ & 10 & 37 & $1.93(0.86-4.35)$ & 0.159 \\
\hline
\end{tabular}

$N=$ number of samples, $\mathrm{OR}=$ odd ratio, $\mathrm{CI}=$ confidence interval, $\mathrm{Ile}=$ isoleucine, $\mathrm{Val}=$ valine 
risk of GIC in both genders (Chong et al. 2014). We included the genotype analysis of the Phe31Ile and Val57Ile SNPs for both genders in this study and found no significant association of gender in both SNPs with GIC risk. Besides, Malaysia is a multi-ethnic country including a majority of Malay, Chinese and Indians in West Malaysia and indigenous ethnics such as Kadazan-Dusun and Bajau in East Malaysia and SNPassociation to GIC might be different across ethnicities. We observed no significant association of different ethnicities in both SNPs towards risk of GIC. Taken together, our study showed that etiological factors including age, gender, and ethnicity are not the risk factors for GIC in the Malaysian population.

\section{CONCLUSION}

We hereby conclude that the 31Ile allele and the 31Ile/Ile genotype in the STK15 Phe31Ile SNP significantly elevated the risk to GIC, particularly in gastric cancer. Despite that age and STK 15 SNPS were not interacting factors associated with GIC, we recommend that screening for GIC should be done before 50 years old as GIC incidences have been alarmingly shifted to younger populations among Malaysians. As etiological factors such as age, gender and ethnicity are not risk factors for GIC in the Malaysian population, gene-gene and gene-environmental interactions should be taken into the account in future study with larger sample sizes for better risk estimation.

\section{ACKNOWLEDGEMENTS}

We thank the staff in Blood Bank Unit, Women and Children Hospital, Kota Kinabalu, Sabah for their assistance in this study. This study was funded by MOSTI ScFund 02-02-10-SF0080.

\section{REFERENCES}

Bischoff, J.R., Anderson, L., Zhu, Y., Mossie, K., Ng, L., Souza, B., Schryver, B., Flanagan, P., Clairvoyant, F., Ginther, C., Chan, C.S., Novotny, M., Slamon, D.J. \& Plowman, G.D. 1998. A homologue of drasophila Aurora kinase is oncogenic and amplified in human colorectal cancer. EMBO Journal 17: 3062-3065.

Chen, G.L., Hou, G.L., Sun, F., Jiang, H.L., Xue, J.F., Li, X.S., Xu, E.H., Gao, W.S. \& Cao, J.P. 2014. Upregulation of STK15 in esophageal squamous cell carcinomas in a Mongolian population. Asian Pacific Journal of Cancer Prevention 15: 6021-6024.

Chen, J., Li, D., Wei, C., Sen, S., Killary, A.M., Amos, C.I., Evans, D.B., Abbruzzese, J.L. \& Frazier, M.L. 2007. Aurora-A and p16 polymorphisms contribute to an earlier age at diagnosis of pancreatic cancer in Caucasian. Clinical Cancer Research 13: 3100-3104.

Cheng, J.L., Randall, A. \& Baldi, P. 2006. Prediction of protein stability changes for single-site mutations using support vector machines. Proteins: Structure, Function and Bioinformatics 62: 1125-1132.

Chong, E.T.J., Goh, L.P.W., See, E.U.H., Chuah, J.A., Chua, K.H. \& Lee, P.C. 2016. Association of CYP2E1,STK15 and XRCC1 polymorphisms with risk of breast cancer in Malaysia women. Asian Pacific Journal of Cancer Prevention 17: 647-653.

Chong, E.T.J., Lee, C.C., Chua, K.H., Chuah, J.A. \& Lee, P.C. 2014. RsaI but not DraI polymorphism in CYP2E1 gene increases the risk of gastrointestinal cancer in Malaysians: A case-control study. BMJ Open 4: e004109.

Dai, Q., Cai, Q.Y., Shu, X.O., Ewart-Toland, A., Wen, W.Q., Balmain, A., Gao, Y.T. \& Zheng, W. 2004. Synergistic effects of STK15 gene polymorphisms and endogenous estrogen exposure in the risk of breast cancer. Cancer Epidemiology, Biomarkers \& Prevention 13: 2065-2070.

Dai, Z.J., Kang, H.F., Wang, X.J., Shao, Y.P., Lin, S., Zhao, Y., Ren, H.T., Min, W.L., Wang, M. \& Liu, X.X. 2014. Association between genetic polymorphisms in AURKA (rs2273535 and rs1047972) and breast cancer risk: A metaanalysis involving 37,221 subjects. Cancer Cell International 14: 91.

Department of Health Statistics. 2013. Health Indicators 20052010. Kuala Lumpur: Ministry of Health Press. p. 98.

Dogan, I., Ekmekci, A., Yurdakul, A.S., Onen, I.H., Ozturk, C., Cirak, M.Y., Acar, A. \& Konac, E. 2008. Polymorphism in the Aurora-A gene is not associated with lung cancer in the Turkish population. DNA and Cell Biology 27: 443-448.

Dutertre, S., Descamps, S. \& Prigent, C. 2002. On the role of aurora-A in centrosome function. Oncogene 21: 6175-6183.

Ewart-Toland, A., Dai, Q., Gao, Y.T., Nagase, H., Dunlop, M.G., Farrington, S.M., Barnetson, R.A., Anton-Culver, H., Peel, D., Ziogas, A., Lin, D., Miao, X., Sun, T., Ostrander, E.A., Stanford, J.L., Langlois, M., Chan, J.M., Yuan, J., Harris, C.C., Bowman, E.D., Clayman, G.L., Lippman, S.M., Lee, J.J., Zheng, W. \& Balmain, A. 2005. Aurora-a/STK15 T+91A is a general low penetrance cancer susceptibility gene: A meta-analysis of multiple cancer types. Carcinogenesis 26: 1368-1373.

Ewart-Toland, A., Briassouli, P., de Koning, J.P., Mao, J.H., Yuan, J., Chan, F., MacCarthy-Morrogh, L., Ponder, B.A., Nagase, H., Burn, J., Ball, S., Almeida, M., Linardopoulos, S. \& Balmain, A. 2003. Identification of STK6/STK15 as a candidate low-penetrance tumor-susceptibility gene in mouse and human. Nature Genetics 34: 403-412.

Gu, J., Gong, Y., Huang, M., Lu, C., Spitz, M.R. \& Wu, X. 2007. Polymorphism of STK15 (Aurora-A) gene and lung cancer risk in Caucasians. Carcinogenesis 28: 350-355.

Honda, K., Mihara, H., Kato, Y., Yamaguchi, A., Tanaka, H., Yasuda, H., Furukawa, K. \& Urano, T. 2000. Degradation of human Aurora 2 protein kinase by the anaphase promoting complex-ubiquitin-proteasome pathway. Oncogene 19: 2812-2819.

International Agency for Research on Cancer. 2014. World Cancer Report 2014. Geneva: World Health Organization Press. pp. 374-421.

Ju, H., Cho, H., Kim, Y.S., Kim, W.H., Ihm, C., Noh, S.M., Kim, J.B., Hahn, D.S., Choi, B.Y. \& Kang, C. 2006. Functional polymorphism 57Val>Ile of Aurora kinase A associated with increased risk of gastric cancer progression. Cancer Letters 242: 273-279.

Kimura, M.T., Mori, T., Conroy, J., Nowak, N.J., Satomi, S., Tamai, K. \& Nagase, H. 2005. Two functional coding single nucleotide polymorphisms in STK15 (Aurora-A) coordinately increase esophageal cancer risk. Cancer Research 65: 35483554.

Malaysian Gastro-Intestinal Registry. 2009. 1st Report 2009: Include Endoscopic Procedures from National Endoscopy 
Registry. Kuala Lumpur: Clinical Research Centre Press. pp. 17-22.

Miao, X., Sun, T., Wang, Y., Zhang, X., Tan, W. \& Lin, D. 2004. Functional STK15 Phe31Ile polymorphism is associated with the occurrence and advanced disease status of esophageal squamous cell carcinoma. Cancer Research 64: 2680-2683.

Pan, J.Y., Ajani, J.A., Gu, J., Gong, Y., Qin, A., Hung, M., Wu, X. \& Izzo, J.G. 2012. Association of Aurora-A (STK15) kinase polymorphisms with clinical outcome of esophageal cancer treated with preoperative chemoradiation. Cancer 118: 4346-4353.

Qin, J., He, X.F., Wei, W., Liu, Z.Z., Xie, J.J., Wang, W., Du, Y.P., Chen, Y. \& Si, H.Q. 2015. Association between the STK15 polymorphisms and risk of cancer: A meta-analysis. Molecular Genetics and Genomics 1: 97-114.

Sakakura, C., Hagiwara, A., Yasuoka, R., Fujita, Y., Nakanishi, M., Masuda, K., Shimomura, K., Nakamura, Y., Inazawa, J., Abe, T. \& Yamagishi, H. 2001. Tumour-amplified BTAK is amplified and overexpressed in gastric cancer with possible involvement in aneuploid formation. British Journal of Cancer 84: 824-831.

Tang, W.F., Qiu, H., Ding, H., Sun, B., Wang, L.X., Yin, J. \& Gu, H.Y. 2013. Association between the STK15 F31I polymorphism and cancer susceptibility: A meta-analysis involving 43,626 subjects. PLOS ONE 8: e82790.

Xu, L., Zhou, X., Jiang, F., Xu, L. \& Yin, R. 2014. STK15 rs2273535 polymorphism and cancer risk: A meta-analysis of 74,896 subjects. Cancer Epidemiology 38: 111-117.
TianXin Lai, Eric Tzyy Jiann Chong \& Ping-Chin Lee* Biotechnology Programme

Faculty of Science and Natural Resources

Universiti Malaysia Sabah, Jalan UMS

88400 Kota Kinabalu, Sabah Negeri di Bawah Bayu

Malaysia

Jitt Aun Chuah

Surgery Department

Queen Elizabeth Hospital, Jalan Penampang

88200 Kota Kinabalu, Sabah Negeri di Bawah Bayu

Malaysia

Kek Heng Chua

Department of Biomedical Science

Faculty of Medicine Building, University of Malaya 50603 Kuala Lumpur, Federal Territory

Malaysia

*Corresponding author; email: leepc@ums.edu.my

Received: 15 January 2016

Accepted: 3 June 2017 